\title{
New assessment of Least Concern lichens in the Red List of Estonia: are common species still common?
}

\author{
Tiina Randlane, Inga Jüriado, Polina Degtjarenko \& Andres Saag \\ University of Tartu, Institute of Ecology and Earth Sciences, J. Liivi Str. 2, 50409 Tartu, Estonia. \\ E-mail: tiina.randlane@ut.ee
}

\begin{abstract}
The threat status of 161 lichenized species that were considered common in Estonia was assessed in 2021. For most of these species, it was the second Red List assessment using the IUCN system (the first such evaluation was performed in 2008). The main data sources for species occurrence were the records reported in 100 study sites located throughout the country during 2020, and the PlutoF biodiversity database. 125 species remained, according to the new assessment, in the category Least Concern (LC) and their populations are not under threat in Estonia at present. Two species were placed in the category Not Applicable (NA) because of systematic revisions while 33 species were assigned to the categories Endangered (EN), Vulnerable (VU) or Near Threatened (NT); one further species received the status Data Deficient (DD). Thus, the threat status has changed for $22 \%$ of the studied species that had generally been considered common in Estonia. The reasons for this change are variable but there is clear evidence that 26 species have already become or will probably become more threatened in the future.
\end{abstract}

Kokkuvôte: 2021 . aastal hinnati 161 Eestis tavaliseks peetud samblikuliigi ohustatust. Neist enamiku jaoks oli see teine IUCN süsteemil póhinev punase raamatu hindamine (esimene selline hindamine toimus 2008. aastal). Peamised liikide esinemise andmeallikad olid 2020. aasta kirjed 100 uuringualalt, mis paiknesid enam-vähem ühtlaselt kogu Eestis, ja PlutoF eElurikkuse andmebaasi kirjed. Uute hindamiste kohaselt jäid 125 liiki kategooriasse 'Soodsas seisundis' (LC) ning nende liikide populatsioonid ei ole praegu Eestis ohustatud. Kahele liigile omistati kategooria 'Mittehinnatav' (NA) muudatuste tôttu nende süstemaatikas ja 33 liiki paigutati kategooriatesse: 'Väljasuremisohus' (EN), 'Ohualdis' (VU) vôi 'Ohulähedane' (NT); üks liik sai kategooria 'Puuduliku andmestikuga' (DD). Ohuhinnang muutus 22\%-1 Eestis üldiselt tavalisteks peetud ja selle projekti käigus uuritud liikidest. Póhjused ohuhinnangute muutmiseks on erinevad, kuid 26 liigi puhul on selge, et nende ohustatus on juba suurenenud vôi see tôenäoliselt suureneb tulevikus.

Keywords: frequent lichens, IUCN, lichen habitats, threat status

\section{INTRODUCTION}

The threat status of Estonian lichens has been assessed four times, in 1988, 1998, 2008, and during 2019-2021 (the process is still ongoing). In 1988 and 1998, the used system of threat categories was conventional and applied criteria were not strictly defined but appeared to be mainly intuitive (Randlane et al., 2008; Lõhmus et al., 2019); furthermore, the knowledge about the Estonian lichen biota was rather limited at that time. Internationally accepted IUCN threat categories and strictly established criteria (Standards and Petitions Working Group, 2006) were applied for the first time in Estonia in 2008 (Tartes, 2010). Then, 464 species of lichenized, lichenicolous or closely allied fungi were evaluated while 555 species remained in the category Not Evaluated (NE). Of the evaluated species, 251 were assessed as Least Concern (LC) and 213 were assigned to one of the following categories: Regionally Extinct (RE), Critically Endangered (CR), Endangered (EN),
Vulnerable (VU), Near Threatened (NT) or Data Deficient (DD) (Randlane et al., 2008). Category Not Applicable (NA) was not used.

The second assessment of the threat status of Estonian lichens based on IUCN system was started in 2019. At that time, 1179 species of lichenized, lichenicolous and closely allied fungi, of which 952 species are lichen-forming, were known in Estonia. Of these, 229 lichenized species were addressed as the first part of the new evaluation. The main basis for choosing the species to be newly assessed were the lists of legally protected lichens and of the species assigned to the Red List categories RE, CR, EN, VU, NT and DD in 2008. Species that had been assessed as LC in 2008 were not re-evaluated then (Lõhmus et al., 2019).

The second round of IUCN-based red-listing process of Estonian lichens which started in 2019 has been prolonged for several years due to organizational and financial reasons, and is still 
not finished. By now, two other lichen evaluation projects have been completed and two more are in progress. In this article, we present the evalution results of the threat status received by one of the finished projects (titled "Contemporay state and threat status of common lichens in Estonia") dealing with 161 lichen species, most of which were assigned to the LC category in 2008; furthermore, we summarize the changes compared to the previous Red List and discuss the probable reasons for those changes.

\section{MATERIAL AND METHODS}

\section{Selection of species}

As the main aim of the project was to re-evaluate the threat status of common lichen species in Estonia, the first source for choosing the species to be currently assessed was the list of lichens that were assigned to the category LC in 2008; it included 251 species (Randlane et al., 2008). A few species that were currently known to be frequent or very frequent (21 or more known localities in Estonia) but were not assessed in 2008 were added to this list as well. Still, several species were left out from the final list of the taxa that were evaluated during this research (Appendix 1) because another project dealing with the assessment of Estonian forest microlichens was in progress at the same time (unpublished data).

\section{Field and lab work}

Targeted field work was carried out in 99 study sites in Estonia during May-September 2020 by Inga Jüriado, Tiina Randlane and Andres Saag. One study site (the Island Kihnu, Pärnu County) was visited in August 2019, to test the methodology of the field work beforehand. Study sites were selected using the base map of the Estonian Land Board (https: / /geoportaal. maaamet.ee) and taking into consideration that: (a) study sites had to be located more or less evenly throughout the territory of the country (Fig. 1); (b) different habitats had to be represented by the study sites whereas the communities recently less investigated in terms of lichens (e.g., old manor parks and cemeteries, coastal areas, rocky habitats etc.) had to be preferred; (c) although forests are the most important community for lichens in the hemiboreal vegetation zone, only a smaller part of our study sites had to be located in forest habitats as forests lichens have been relatively well investigated in Estonia during the last decade (for example, Marmor et al., 2012, 2013, 2017; Lõhmus et al., 2012; Jüriado \& Paal, 2019; Lõhmus \& Lõhmus, 2019, Liira et al., 2020); (d) all our forest study sites had to be located in protected territories.

The presence or absence of previously listed 161 lichen species was recorded in every study plot of ca 2 ha during the approximately 3 hours inventory by one researcher investigating all probable lichen substrates. The area and outline of study plots were not strictly limited but covered the territory of a certain habitat types within its natural borders (for example, the whole manor park). Our main interest was to record as many listed species as possible and not to compare the study sites with each other. Most of the species were identified in the field but some specimens (e.g., from the genera Cladonia, Lecanora and Usnea) were collected for further investigation under a stereo- or light microscope and chemical analyses. Standardized thin-layer chromatography (TLC) using solvent system A (Orange et al., 2001) was performed to confirm the identification of lichen compounds in Cladonia chlorophaea group and Usnea species.

The main data source for species occurrence records was the PlutoF biodiversity database (https://plutof.ut.ee) incorporating the data of specimens from all main Estonian herbaria (TALL, TAM and TU), field observations and literature records. All types of data (specimens, observations and literature information) were considered within this evaluation. In addition, the dataset of records collected during the field work of this project was uploaded to the PlutoF database; data of a few other unpublished lichen research projects or inventories in Estonia during 2008-2021 were also taken into account.

The taxonomy follows Randlane et al. (2019).

\section{Assessment of the threat status of species}

Assessment of the threat status of targeted lichen species was carried out during MarchJune 2021 by the first author and the reviews of the assessments were provided by the other three authors. The process was performed using the Estonian Nature Information System EELIS (https://www.eelis.ee); the species assessment sheets (including the relevant map files) are 


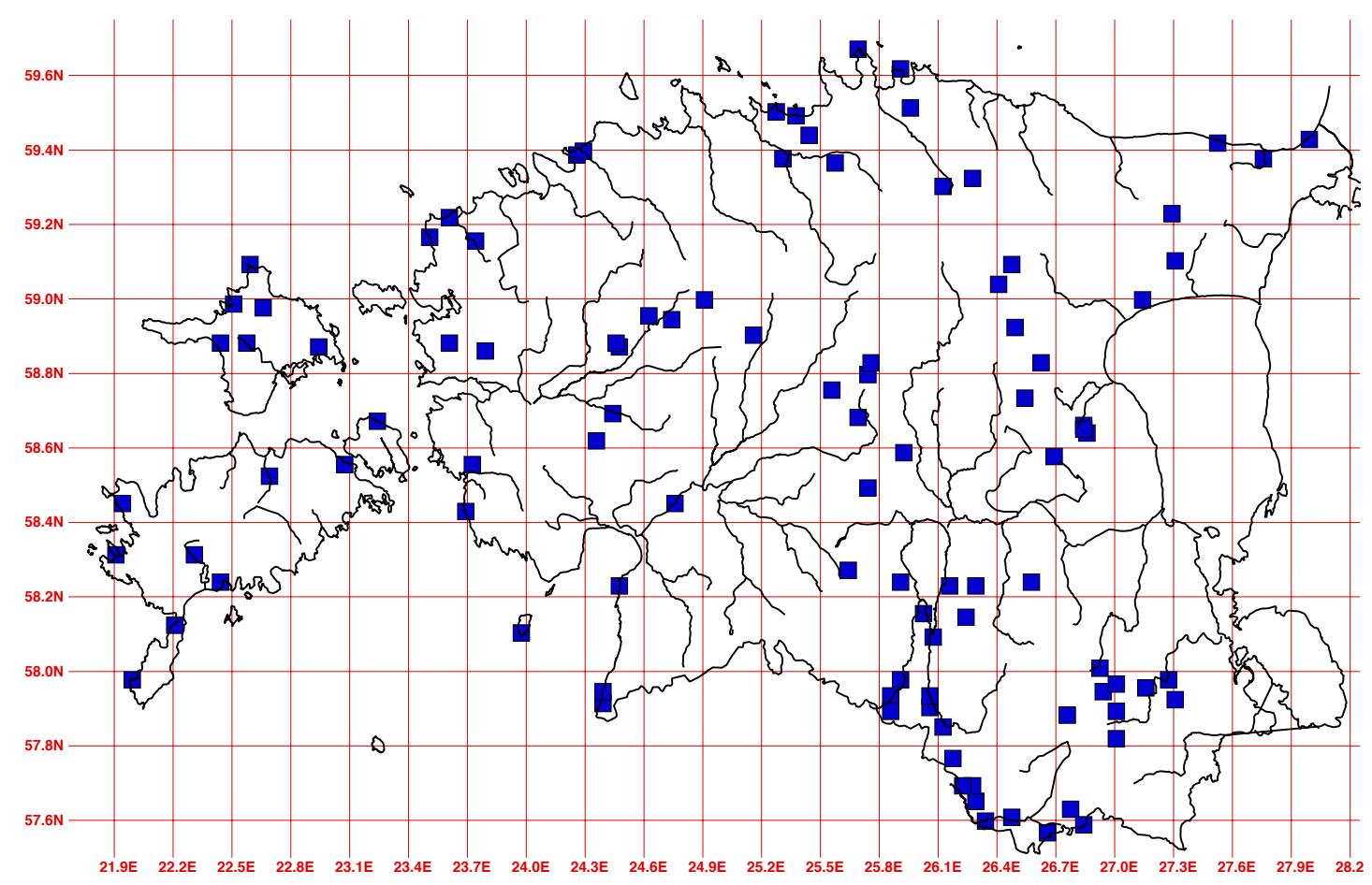

Fig. 1. Location of 100 study sites in Estonia where selected 161 common lichen species were searched in summer 2020.

available to the registered users of this information system. The latest IUCN guidelines (ver. 13) for using the Red List categories and criteria (IUCN Standards and Petitions Subcommittee, 2017) were applied and additionally, guidelines for applying IUCN criteria for fungi (Dahlberg \& Mueller, 2011) were also considered. For more details of the assessment process see Lõhmus et al. (2019).

At first, contemporary distribution maps were compiled for all assessed taxa using the workbench of PlutoF biodiversity database (https:// plutof.ut.ee); for this, all records of the species from the period 2008-2021, i.e. after the previous red data list of Estonia (Tartes, 2008), were taken into account. If the distribution area of the species covered the whole country and the number of recorded subpopulations during this period was over 50 (i.e. corresponding to the frequency class 'Very frequent' according to Randlane \& Saag, 1999), then it was interpreted as no population reduction or decline in geographic range has been taken place, and the species was assessed as LC. Although the observed or suspected decline in the species habitat quality was always considered as an additional constraint, no one taxon with 50 or more subpopulations qualified for any other category than LC.

The lichen species that did not meet the described conditions were further evaluated using the thresholds of IUCN criteria (IUCN Standards and Petitions Subcommittee, 2017) and the following techniques were applied throughout this project. Applying the IUCN criterion A (population size reduction), the population reduction was measured as the decline in extent of occurrence (EOO) of a species during the last 30 years (1990-2021). Although it is suggested by the guidelines that the reduction should be measured over 10 years or three generations (whichever is longer) when using the criterion A, the duration of three generations [i.e. 50 years, considering 17 years as the length of 




Fig. 2. Example of measuring the extent of occurrence (EOO) in Estonia on the base map of the Estonian Land Board and calculating its decline; the measured areas are indicated by red ovals in the left sidebar. a - EOO of Cladonia turgida considering all known records of the species is ca $37800 \mathrm{~km}^{2}$; b - EOO of Cladonia turgida during the period 1990-2021 is ca $20900 \mathrm{~km}^{2}$. Decline in $\mathrm{EOO}$ is calculated $55 \%$. 
one generation - the usual estimate for lichens (Gärdenfors, 2005; Pykälä et al., 2019)] seemed not appropriate for the local dataset. If 50 years would have been used as the period for measuring population reduction, recent indications of the decline of several lichens would not have been revealed. It is evident that the environmental conditions, e.g., area and quality of important lichen habitats (e.g., old boreal and nemoral forests, alvar grasslands, wooded meadows etc.), have considerably declined just during the last decades in Estonia (Leppik et al., 2013; Jüriado et al., 2015; Lõhmus \& Lõhmus, 2019). For measuring the decline in EOO, two distribution maps were compiled for each species using the same tools as described above: one map of all known records and another map of records from the period 1990-2021. The areas of EOO were measured using the according tool attached to the base map of the Estonian Land Board (https://geoportaal.maaamet.ee) (Fig. 2), and the decline in percentages was calculated accordingly.

Applying the IUCN criterion B (geographic range and fragmentation or continuing decline), the geographic range of a species was measured as its contemporary EOO, using all records of the species from the period 2008-2021. Criteria C (small population size and decline) and D (very small or restricted population) were regarded as well during the assessments while it was decided not to use the criterion $\mathrm{E}$ (quantitative analysis) due to the insufficiency of data.

\section{RESULTS AND DISCUSSION}

The threat status of 161 lichenized species, which were considered common in Estonia, was assessed (Appendix 1). Of them, 150 species had the category LC already in the previous Red List (Randlane et al., 2008), the status of ten species had not been assessed in 2008 (category NE) but those species were known as frequent or very frequent nationally according to the ranking by Randlane \& Saag (1999), and one species (Candelaria pacifica) was reported as new to Estonia in 2011 (Randlane et al., 2011) and thus had no Red List category from 2008.

The new threat status for the above-mentioned taxa was classified into six IUCN categories (Table 1; Appendix 1).
Table 1. Numbers of lichen species in the IUCN Red List categories according to the assesments of 161 species (Supplement 1) in Estonia in 2021 and 2008. Abbreviations of categories: LC Least Concern, DD - Data Deficient, NT - Near Threatened, VU - Vulnerable, EN - Endangered, NE - Not Evaluated, NA -Not Applicable.

\begin{tabular}{llllllll}
\hline $\begin{array}{l}\text { Red list } \\
\text { category }\end{array}$ & LC & DD & NT & VU & EN & NE & NA \\
\hline $\begin{array}{l}\text { No. of species } \\
\text { according to } \\
\text { the assessment }\end{array}$ & 125 & 1 & 16 & 9 & 8 & - & 2 \\
in 2021 & & & & & & & \\
\hline $\begin{array}{l}\text { No. of species } \\
\text { according to } \\
\text { the assessment } \\
\text { in } 2008\end{array}$ & 150 & - & - & - & - & 10 & $1^{*}$ \\
\hline
\end{tabular}

* As Candelaria pacifica was reported in Estonia only in 2011, the taxon was not assessed in 2008; here it is treated under the category NA.

Two previously separate species, Bryoria subcana and Cladonia bacillaris, were placed in the category NA because of systematic changes (the taxa have been included in Bryoria fuscescens and Cladonia macilenta, accordingly, and their treatment as separate species was not reasonable any longer; Velmala et al., 2014; Stenroos et al., 2016). 125 species remained, according to the new assessment, in the category LC and their populations are not under threat in Estonia at present. 33 species were assigned the categories EN, VU or NT (Table 2); one further species received the status DD. RE or CR categories were not appropriate to any of the studied species. A few of those species that were LC in 2008 but are now considered as threatened or near threatened in Estonia, appear of elevated conservation concern also in Finland or Sweden, according to their latest assessments, viz., Bryoria nadvornikiana, Candelaria concolor, Cladonia norvegica, C. polydactyla, Peltigera membranacea, Ramalina baltica, and Usnea glabrescens (Table 2). Comparison with the Red List of Polish lichens (Cieśliński et al., 2003) reveals that majority of those taxa that were newly assessed as threatened or near threatened in Estonia are also either extinct, threatened or near threatened in Poland (Table 2). Evidently, the lichens that have tendency to be distributed in the northern or mountainous areas (e.g., 
Cladonia acuminata, C. cyanipes, Stereocaulon saxatile, Xylopsora friesii, etc.), are similarly threatened or rare in Estonia and Poland but frequent in Fennoscandia.

The threat status has changed for $22 \%$ of the species that had generally been considered common in Estonia. The reasons for the change are variable. Firstly, it is possible that the category LC was assigned to six lichens (Bryoria implexa, B. nadvornikiana, Cladonia pleurota, C. polydactyla, Rhizocarpon geographicum and Xylopsora caradocensis) erroneously in 2008. This opinion is confirmed by the fact that some herbarium samples of these species have been re-identified as belonging to other species; however, correct backward assessments are not possible because records referred to as 'literature data' or 'observations' in the database cannot be verified or rejected nowadays. It means, in our opinion, that these species have not become more threatened during the last assessment period, but they have been under some threat already earlier.

One species, Candelaria concolor, is a recent example how changes in systematics bring along better understanding about the threat status of taxa. Candelaria concolor was considered a common lichen throughout Europe until 2011. In 2011, a new species, Candelaria pacifica, was described (Westberg \& Arup, 2011), and reported also in Estonia at the same year (Randlane et al., 2011). During the Red List assessments in 2008 these two taxa were not separated and $C$. concolor was assigned to the category LC. The current assessment revealed that $C$. concolor has been reliably recorded in Estonia altogether in three subpopulations (Nõmme, Harjumaa County in 1912; Roosna-Alliku, Järvamaa County in 1987, and Mäetaguse, Ida-Virumaa County in 2020) and was accordingly assessed as EN while C. pacifica is common throughout the country and was assessed as LC.

One more species, Usnea lapponica, which was evaluated as LC in 2008 was now assigned to the category DD as only two records from one subpopulation (in Taevaskoja, Põlva County) have been reported during the period 2008-2021, while 53 specimens of this taxon had been documented previously in Estonia (Tõrra \& Randlane, 2007). It is theoretically possible that this drastic decline in the recorded subpopulations is not caused by the serious changes in the habitat conditions suitable for the lichen, but by generally much poorer reporting of certain Usnea species in Estonia during recent years. Still, radical population reduction is also possible. This means that the data available for the assessment are so uncertain that both $\mathrm{CR}$ and LC are currently plausible categories for U. lapponica, and therefore DD can be considered the suitable category (IUCN Standards and Petitions Subcommittee, 2017).

The rest 26 species that involve the species of elevated conservation concern (i.e., the categories EN, VU or NT) have evidently already become or will propably become more threatened in the future, based on the present data. These lichens inhabit old-growth or mature forests (e.g., Cladonia norvegica, Hypogymnia farinacea, Peltigera neopolydactyla etc.), sandy dunes, dry heathlands or boreal heath forests (e.g., Cetraria muricata, Cladonia cariosa, Stereocaulon tomentosum etc.), alvar grasslands (Diploschistes muscorum), old parks (Ramalina baltica) and siliceous boulders in open habitats (e.g., Ramalina subfarinacea, Umbilicaria torrefacta etc.) (Table 2). The listed natural habitats are mainly the same that have been pointed out earlier as declining in Estonia and which endangerment has been discussed in relation to lichens repeatedly (Leppik et al., 2013, 2015; Jüriado et al., 2016; Marmor et al., 2017; Lõhmus et al., 2019). Based on this list of lichens with elevated conservation concern (Table 2), we want to point out the importance of boreal heath forests, dry heathlands and sandy dunes as suitable habitats for the threatened lichens that have received less attention so far. Some main threat factors of Estonian lichens such as extensive industrial management of forests and overgrowing of open habitats (dunes, heathlands and alvars) due to the cessation of traditional maintenance are known for a long time, but still continuously actual. This means that current nature conservational measures concerning lichens have not been effective. Some other threat factors, e.g. those influencing the epilithic lichens on erratic boulders, have been less discussed. Epilithic lichens are evidently also influenced by the overgrowing of open habitats as erratic boulders in shaded localities are less rich in lichens and more inhabited by mosses (Fletcher, 2001; Giordani et al., 2010). Trampling on erratic boulders, especially on 


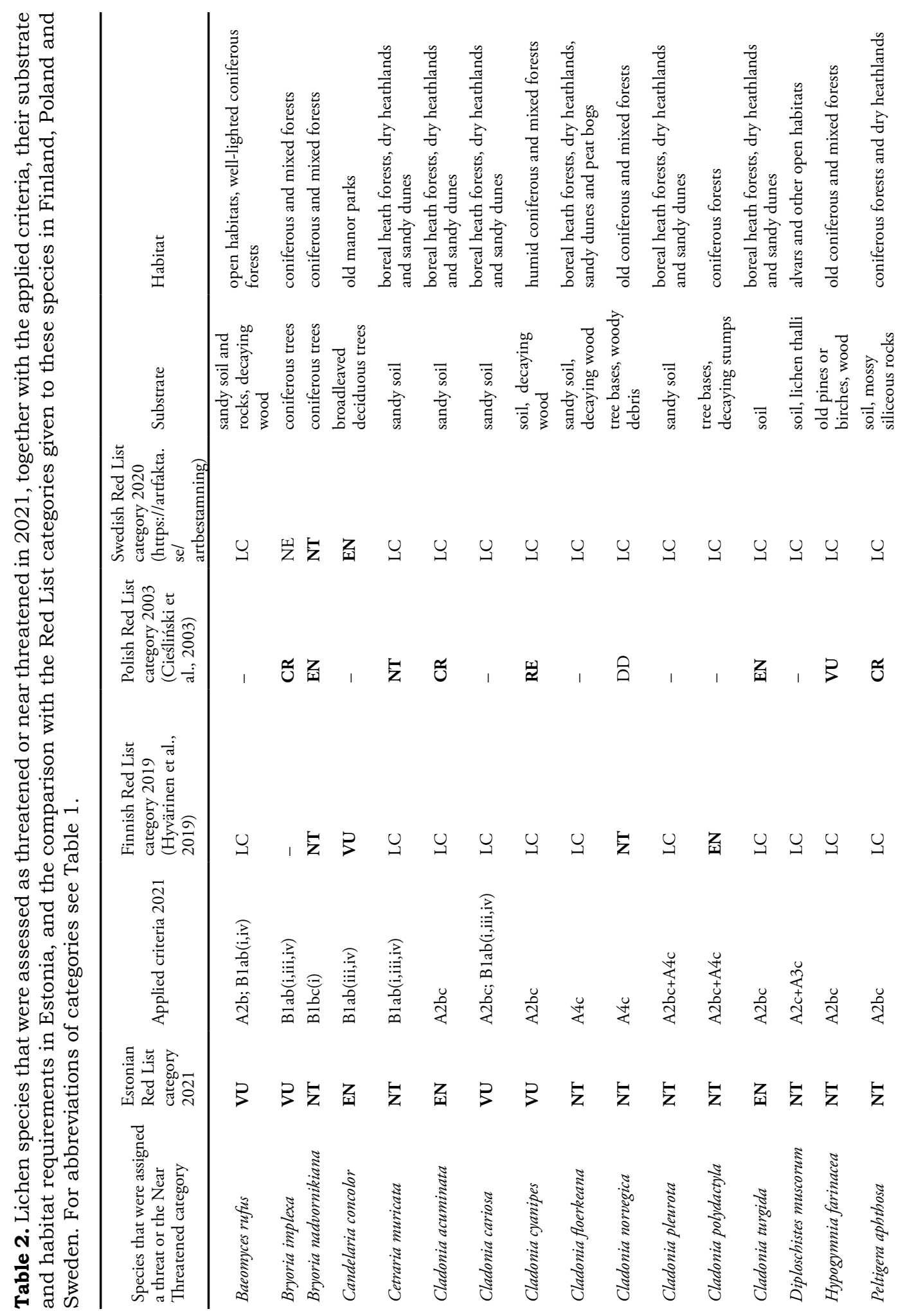




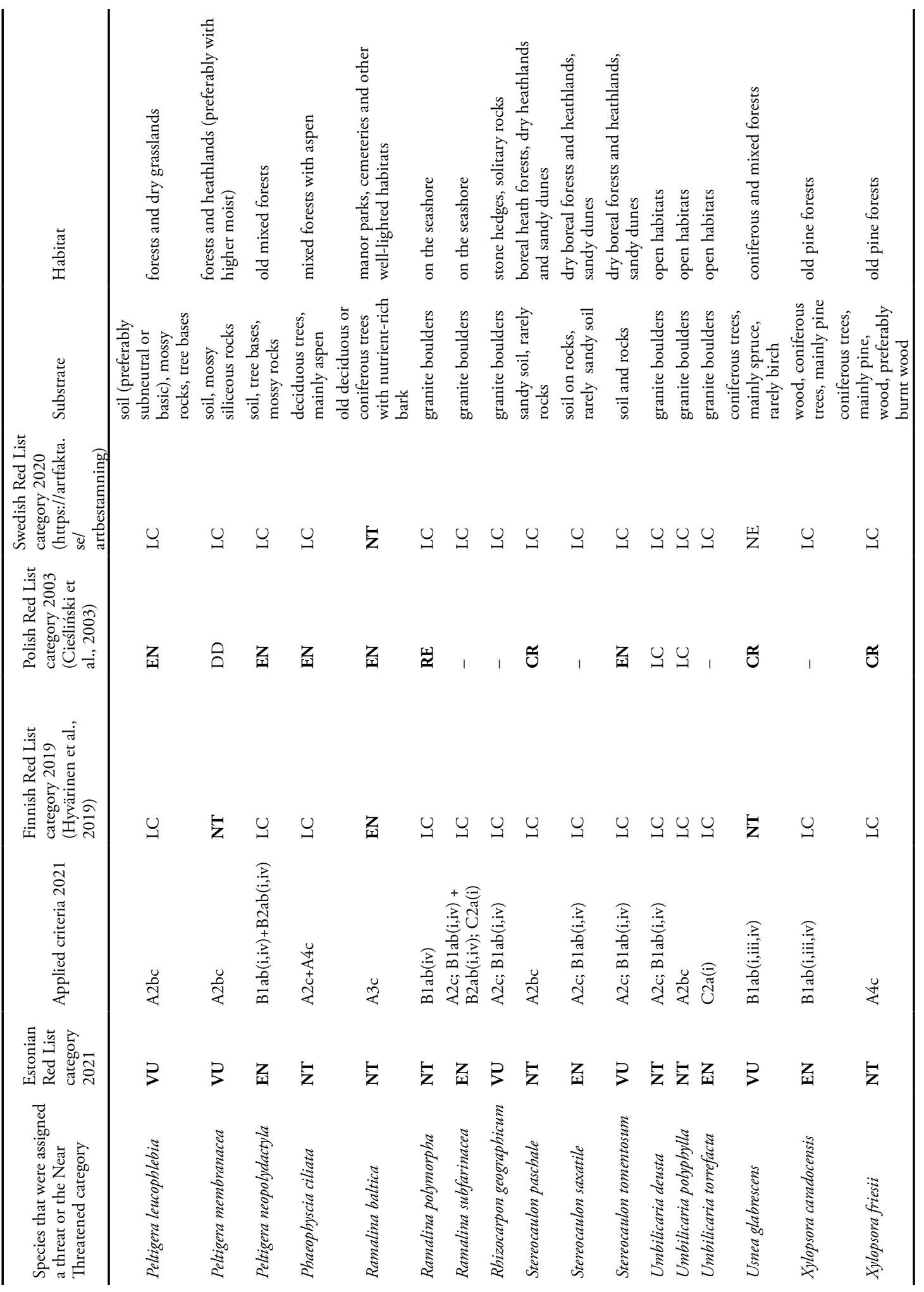


bigger boulders, appears as direct anthropogenic threat factor of epilithic lichens; this is seen, for example, close to the hiking trails.

The summarizing answer to the question raised in the title of the present paper is: the majority of common lichen species $(78 \%$ of those taxa that were assessed in this research) are continuously common in Estonia according to the present knowledge, while the threat status for $16 \%$ of the studied species has deteriorated. The change of threat status for the remaining $6 \%$ of taxa cannot be reliably evaluated due to different reasons, such as previous incorrect assessment of the threat status or systematic changes. However, the relative proportions between the least concerned and threatened or near threatened species may be modified in the future as the new round of red-listing of Estonian lichens is still in process.

\section{ACKNOWLEDGEMENTS}

The research was financed by the project no. 15878 of the Environmental Investment Centre (KIK). We are grateful to our colleagues Piret Lõhmus, Liis Marmor-Ohtla and Ave Suija for the additional lichen data and discussions concerning the assessment of some species. The authors thank the Reviewer and also Piret Lõhmus for valuable comments on the manuscript.

\section{REFERENCES}

Cieśliński, S., Czyżewska, K. \& Fabiszewski, J. 2003. Red list of extinct and threatened lichens in Poland. Monographiae Botanicae 91: 13-49.

Dahlberg, A. \& Mueller, G. M. 2011. Applying IUCN red-listing criteria for assessing and reporting on the conservation status of fungal species. Fungal Ecology 4(2): 147-162.

Fletcher, A. 2001. Lowland rocks and lichens. In: Fletcher, A., Wolseley, P. \& Woods, R. (eds.) Lichen Habitat Management, pp. 10-15. British Lichen Society.

Gärdenfors, U. (ed.) 2005. The 2005 Red List of Swedish species. Artdatabanken, SLU, Uppsala. 496 pp.

Giordani, P., Incerti, G., Rizzi, G., Ginaldi, F., Viglione, S., Rellini, I., Brunialti, G., Malaspina, P. \& Modenesi, P. 2010. Land use intensity drives the local variation of lichen diversity in Mediterranean ecosystems sensitive to desertification. Bibliotheca Lichenologica 105: 139-148.

Hyvärinen, E., Juslén, A., Kemppainen, E., Uddström, A. \& Liukko, U.-M. (eds.) 2019. The 2019 Red List of Finnish Species. Ympäristöministeriö \& Suomen ympäristökeskus, Helsinki. 704 pp.

IUCN Standards and Petitions Subcommittee, 2017. Guidelines for Using the IUCN Red List Categories and Criteria. Version 13. Prepared by the Standards and Petitions Subcommittee. http://www. iucnredlist.org/documents / RedListGuidelines. pdf.

Jüriado, I., Kämärä, M.-L. \& Oja, E. 2016. Environmental factors and ground disturbance affecting the composition of species and functional traits of ground layer lichens on grey dunes and dune heaths of Estonia. Nordic Journal of Botany 34(2): 244-255.

Jüriado, I., Leppik, E., Lõhmus, P., Randlane, T. \& Liira, J. 2015. Epiphytic lichens on Juniperus communis - an unexplored component of biodiversity in threatened alvar grassland. Nordic Journal of Botany 33: 128-139.

Jüriado, I. \& Paal, J. 2019. Epiphytic lichen synusiae and functional trait groups in boreo-nemoral deciduous forests are influenced by host tree and environmental factors. Nordic Journal of Botany 2019: e01939.

Leppik, E., Jüriado, I., Suija, A. \& Liira, J. 2013. The conservation of ground layer lichen communities in alvar grasslands and the relevance of substitution habitats. Biodiversity and Conservation 22: 591-614.

Leppik, E., Jüriado, I., Suija, A. \& Liira, J. 2015. Functional ecology of rare and common epigeic lichens in alvar grasslands. Fungal Ecology 13: 66-76.

Liira, J., Suija, A. \& Jüriado, I. 2020. Habitat and host specificity of epiphytic lichens in a rural landscape: cultural heritage habitats as refugia. Biodiversity and Conservation 29: 2141-2160.

Lõhmus, P., Leppik, E., Motiejunaite, J., Suija, A. \& Lõhmus, A. 2012. Old selectively cut forests can host rich lichen communities - lessons from an exhaustive eld survey. Nova Hedwigia 95: 493-515.

Lõhmus, P. \& Lõhmus, A. 2019. The potential of production forests for sustaining lichen diversity: a perspective on sustainable forest management. Forests 10: ARTN 1063.

Lõhmus, P., Marmor, L., Jüriado, I., Suija, A., Oja, E., Degtjarenko, P. \& Randlane, T. 2019. Red List of Estonian lichens: revision in 2019. Folia Cryptogamica Estonica 56: 63-76.

Marmor, L., Tõrra, T., Saag, L. \& Randlane, T. 2012. Species richness of epiphytic lichens in coniferous forests: the effect of canopy openness. Annales Botanici Fennici 49: 352-358.

Marmor, L., Tõrra, T., Saag, L., Leppik, E. \& Randlane, T. 2013. Lichens on Picea abies and Pinus sylvestris - from tree bottom to the top. Lichenologist 45: 51-63.

Marmor, L., Randlane, T., Jüriado, I. \& Saag, A. 2017. Host tree preferences of red-listed epiphytic lichens in Estonia. Baltic Forestry 23: 364-373. 
Pykälä, J., Jääskeläinen, K., Rämä, H., Launis, A., Vitikainen, O. \& Puolasmaa, A. 2019. Lichens. In: The 2019 Red List of Finnish species. Helsinki, pp. 263-312.

Randlane, T., Jüriado, I., Suija, A., Lõhmus, P. \& Leppik, E. 2008. Lichens in the new Red List of Estonia. Folia Cryptogamica Estonica 44: 113-120.

Randlane, T. \& Saag, A. (eds). 1999. Second checklist of lichenized, lichenicolous and allied fungi of Estonia. Folia Cryptogamica Estonica 35: 1-132.

Randlane, T., Saag, A., Martin, L., Timdal, E. \& Nimis, P. L. 2011. Epiphytic macrolichens of Estonia. Tartu Ülikooli Kirjastus, Tartu. 326 pp.

Randlane, T., Saag, A. \& Suija, A. 2019. Lichenized, lichenicolous and allied fungi of Estonia. Ver. December 31, 2019 - http: / / esamba.bo.bg.ut.ee/ checklist/est/home.php (assessed on 29.09.2021).

Stenroos, S., Velmala, S., Pykälä, J. \& Ahti, T. (eds.) 2016. Lichens of Finland. Norrlinia 30: 1-896.

Standards and Petitions Working Group 2006. Guidelines for Using the IUCN Red List Categories and Criteria: Version 6.1. Prepared by the Standards and Petitions Working Group for the IUCN SSC Biodiversity Assessments Sub-Committee in July
2006. Downloadable from http://app.iucn.org/ webfiles/doc/SSC/RedList/RedListGuidelines. pdf.

Tartes, U. 2010. Punane nimestik ja liigikaitse. In: Eesti Teaduste Akadeemia seminari materjalid. Rahvusvahelise elurikkuse aasta 2010. Tallinn, 1k. 4-8. (In Estonian).

The Swedish Red List 2020. https://artfakta.se/artbestamning (assessed on 29.09.2021).

Tõrra, T. \& Randlane, T. 2007. The lichen genus Usnea (lichenized Ascomycetes, Parmeliaceae) in Estonia with a key to the species in the Baltic countries. Lichenologist 39: 415-438.

Velmala, S., Myllys, L., Goward, T., Holien, H. \& Halonen, P. 2014. Taxonomy of Bryoria section Implexae (Parmeliaceae, Lecanoromycetes) in North America and Europe, based on chemical, morphological and molecular data. Annales Botanici Fennici 51: 345-371.

Westberg, M. \& Arup, U. 2011. Candelaria pacifica sp. nova (Ascomycota, Candelariales) and the identity of Candelaria vulgaris. Bibiotheca Lichenologica 106: 353-364. 
Appendix 1. Red-listed lichens according to the evaluation performed within the project "Contemporary state and threat status of common lichens in Estonia" together with their IUCN categories assigned in 2021 and 2008. Abbreviations of categories: LC - Least Concern, DD - Data Deficient, NT - Near Threatened, VU - Vulnerable, EN - Endangered, NE - Not Evaluated, NA - Not Applicable.

\begin{tabular}{|c|c|c|c|c|}
\hline $\begin{array}{l}\text { Species name (in bold if the species was assigned a threat } \\
\text { or the Near Threatened category) }\end{array}$ & $\begin{array}{l}\text { Species name used in } \\
2008\end{array}$ & $\begin{array}{l}\text { Red List } \\
\text { category in } \\
2021\end{array}$ & $\begin{array}{l}\text { Red List } \\
\text { category in } \\
2008\end{array}$ & Comments \\
\hline Acarospora fuscata (Nyl.) Arnold & & LC & $\mathrm{NE}$ & \\
\hline Anaptychia ciliaris (L.) Körb. & & $\mathrm{LC}$ & LC & \\
\hline Aspicilia cinerea (L.) Körb. & & $\mathrm{LC}$ & LC & \\
\hline Athallia scopularis (Nyl.) Arup, Frödén \& Søchting & Caloplaca scopularis & $\mathrm{LC}$ & LC & \\
\hline Athallia vitellinula (Nyl.) Arup, Frödén \& Søchting & Caloplaca vitellinula & $\mathrm{LC}$ & $\mathrm{NE}$ & \\
\hline Baeomyces rufus (Huds.) Rebent. & & VU & LC & \\
\hline Bryoria capillaris (Ach.) Brodo \& D. Hawksw. & & $\mathrm{LC}$ & LC & \\
\hline Bryoria fuscescens (Gyeln.) Brodo \& D. Hawksw. & & $\mathrm{LC}$ & LC & $\begin{array}{l}\text { includes also } \\
\text { Bryoria subcana }\end{array}$ \\
\hline Bryoria implexa (Hoffm.) Brodo \& D. Hawksw. & & VU & LC & \\
\hline Bryoria nadvornikiana (Gyeln.) Brodo \& D. Hawksw. & & NT & LC & \\
\hline Bryoria subcana (Nyl. ex Stizenb.) Brodo \& D. Hawksw. & & NA & LC & $\begin{array}{l}\text { was not evaluated } \\
\text { as a separate } \\
\text { species, included } \\
\text { in Bryoria } \\
\text { fuscescens }\end{array}$ \\
\hline Calogaya decipiens (Arnold) Arup, Frödén \& Søchting & Caloplaca decipiens & $\mathrm{LC}$ & LC & \\
\hline Calogaya saxicola (Hoffm.) Vondrák & Caloplaca saxicola & $\mathrm{LC}$ & LC & \\
\hline Candelaria concolor (Dicks.) Stein & & EN & LC & \\
\hline Candelaria pacifica M. Westb. \& Arup & & $\mathrm{LC}$ & - & $\begin{array}{l}\text { new to Estonia in } \\
2011\end{array}$ \\
\hline Candelariella coralliza (Nyl.) H. Magn. & & $\mathrm{LC}$ & LC & \\
\hline Cetraria aculeata (Schreb.) Fr. & & $\mathrm{LC}$ & LC & \\
\hline Cetraria ericetorum Opiz & & $\mathrm{LC}$ & LC & \\
\hline Cetraria islandica (L.) Ach. & & $\mathrm{LC}$ & LC & \\
\hline Cetraria muricata (Ach.) Eckfeldt & & NT & LC & \\
\hline Cetraria sepincola (Ehrh.) Ach. & & $\mathrm{LC}$ & LC & \\
\hline Circinaria calcarea (L.) A. Nordin, Savić \& Tibell & Aspicilia calcarea & $\mathrm{LC}$ & $\mathrm{NE}$ & \\
\hline $\begin{array}{l}\text { Circinaria hoffmanniana (S. Ekman \& Fröberg ex R. } \\
\text { Sant.) A. Nordin }\end{array}$ & $\begin{array}{l}\text { Aspicilia contorta ssp. } \\
\text { hoffmanniana }\end{array}$ & $\mathrm{LC}$ & LC & \\
\hline Cladonia acuminata (Ach.) Norrl. & & EN & LC & \\
\hline Cladonia arbuscula (Wallr.) Flot. & Cladina arbuscula & $\mathrm{LC}$ & LC & \\
\hline Cladonia bacillaris (Leight.) Arnold & & NA & $\mathrm{LC}$ & $\begin{array}{l}\text { was not evaluated } \\
\text { as a separate } \\
\text { species, included } \\
\text { in Cladonia } \\
\text { macilenta }\end{array}$ \\
\hline Cladonia bacilliformis (Nyl.) Glück & & $\mathrm{LC}$ & LC & \\
\hline Cladonia botrytes (K.G. Hagen) Willd. & & $\mathrm{LC}$ & LC & \\
\hline Cladonia cariosa (Ach.) Spreng. & & VU & LC & \\
\hline Cladonia cenotea (Ach.) Schaer. & & $\mathrm{LC}$ & LC & \\
\hline Cladonia cervicornis ssp. verticillata (Hoffm.) Ahti & Cladonia verticillata & $\mathrm{LC}$ & $\mathrm{NE}$ & \\
\hline Cladonia chlorophaea (Flörke ex Sommerf.) Spreng. & & $\mathrm{LC}$ & LC & \\
\hline Cladonia ciliata var. tenuis (Flörke) Ahti & Cladina ciliata var. tenuis & $\mathrm{LC}$ & LC & \\
\hline Cladonia coniocraea (Flörke) Spreng. & & $\mathrm{LC}$ & LC & \\
\hline Cladonia cornuta (L.) Hoffm. & & $\mathrm{LC}$ & $\mathrm{LC}$ & \\
\hline
\end{tabular}




\begin{tabular}{|c|c|c|c|c|}
\hline $\begin{array}{l}\text { Species name (in bold if the species was assigned a threat } \\
\text { or the Near Threatened category) }\end{array}$ & $\begin{array}{l}\text { Species name used in } \\
2008\end{array}$ & $\begin{array}{l}\text { Red List } \\
\text { category in } \\
2021\end{array}$ & $\begin{array}{l}\text { Red List } \\
\text { category in } \\
2008\end{array}$ & Comments \\
\hline Cladonia crispata (Ach.) Flot. & & LC & $\mathrm{LC}$ & \\
\hline Cladonia cyanipes (Sommerf.) Nyl. & & VU & $\mathrm{LC}$ & \\
\hline Cladonia deformis (L.) Hoffm. & & LC & LC & \\
\hline Cladonia digitata (L.) Hoffm. & & LC & LC & \\
\hline Cladonia fimbriata (L.) Fr. & & LC & LC & \\
\hline Cladonia floerkeana (Fr.) Sommerf. & & NT & LC & \\
\hline Cladonia furcata (Huds.) Schrad. & & $\mathrm{LC}$ & $\mathrm{LC}$ & \\
\hline Cladonia glauca Flörke & & LC & LC & \\
\hline Cladonia gracilis (L.) Willd. & & LC & LC & \\
\hline Cladonia macilenta Hoffm. & & $\mathrm{LC}$ & $\mathrm{LC}$ & $\begin{array}{l}\text { includes also } \\
\text { Cladonia } \\
\text { bacillaris }\end{array}$ \\
\hline Cladonia mitis Sandst. & Cladina mitis & LC & $\mathrm{LC}$ & \\
\hline Cladonia norvegica Tønsberg \& Holien & & NT & $\mathrm{LC}$ & \\
\hline Cladonia ochrochlora Flörke & & LC & $\mathrm{LC}$ & \\
\hline Cladonia phyllophora Hoffm. & & LC & $\mathrm{LC}$ & \\
\hline Cladonia pleurota (Flörke) Schaer. & & NT & $\mathrm{LC}$ & \\
\hline Cladonia polydactyla (Flörke) Spreng. & & NT & LC & \\
\hline Cladonia pyxidata (L.) Hoffm. & & $\mathrm{LC}$ & LC & \\
\hline Cladonia rangiferina (L.) F.H. Wigg. & Cladina rangiferina & LC & $\mathrm{LC}$ & \\
\hline Cladonia rangiformis Hoffm. & & LC & $\mathrm{LC}$ & \\
\hline Cladonia rei Schaer. & & $\mathrm{LC}$ & $\mathrm{LC}$ & \\
\hline Cladonia squamosa Hoffm. & & $\mathrm{LC}$ & $\mathrm{LC}$ & \\
\hline Cladonia stellaris (Opiz) Pouzar \& Vězda & Cladina stellaris & LC & $\mathrm{LC}$ & \\
\hline Cladonia stygia (Fr.) Ruoss & Cladina stygia & LC & $\mathrm{LC}$ & \\
\hline Cladonia subrangiformis Sandst. & & LC & LC & \\
\hline Cladonia subulata (L.) F.H. Wigg. & & LC & LC & \\
\hline Cladonia sulphurina (Michx.) Fr. & & LC & LC & \\
\hline Cladonia symphycarpia (Flörke) Fr. & & $\mathrm{LC}$ & $\mathrm{LC}$ & \\
\hline Cladonia turgida Hoffm. & & EN & $\mathrm{LC}$ & \\
\hline Cladonia uncialis (L.) F.H. Wigg. & & LC & LC & \\
\hline Clauzadea monticola (Schaer.) Hafellner \& Bellem. & & LC & LC & \\
\hline Diploschistes muscorum (Scop.) R. Sant. & & NT & $\mathrm{NE}$ & \\
\hline Evernia prunastri (L.) Ach. & & LC & LC & \\
\hline Hypocenomyce scalaris (Ach.) M. Choisy & & LC & LC & \\
\hline Hypogymnia farinacea Zopf & & NT & LC & \\
\hline Hypogymnia physodes (L.) Nyl. & & $\mathrm{LC}$ & $\mathrm{LC}$ & \\
\hline Hypogymnia tubulosa (Schaer.) Hav. & & $\mathrm{LC}$ & $\mathrm{LC}$ & \\
\hline Imshaugia aleurites (Ach.) S.L.F. Meyer & & $\mathrm{LC}$ & $\mathrm{LC}$ & \\
\hline $\begin{array}{l}\text { Lathagrium fuscovirens (With.) Otálora, P.M. Jørg. \& } \\
\text { Wedin }\end{array}$ & Collema fuscovirens & $\mathrm{LC}$ & $\mathrm{LC}$ & \\
\hline Lecanora albescens (Hoffm.) Branth \& Rostr. & & $\mathrm{LC}$ & $\mathrm{LC}$ & \\
\hline Lecanora crenulata Hook. & & $\mathrm{LC}$ & $\mathrm{NE}$ & \\
\hline Lecanora dispersa (Pers.) Sommerf. & & LC & LC & \\
\hline Lecanora polytropa (Ehrh. ex Hoffm.) Rabenh. & & LC & LC & \\
\hline Lecanora rupicola (L.) Zahlbr. & & LC & LC & \\
\hline Lecanora semipallida $\mathrm{H}$. Magn. & Lecanora flotoviana & $\mathrm{LC}$ & $\mathrm{NE}$ & \\
\hline Lecanora sulphurea (Hoffm.) Ach. & & LC & LC & \\
\hline
\end{tabular}




\begin{tabular}{|c|c|c|c|c|}
\hline $\begin{array}{l}\text { Species name (in bold if the species was assigned a threat } \\
\text { or the Near Threatened category) }\end{array}$ & $\begin{array}{l}\text { Species name used in } \\
2008\end{array}$ & $\begin{array}{l}\text { Red List } \\
\text { category in } \\
2021\end{array}$ & $\begin{array}{l}\text { Red List } \\
\text { category in } \\
2008\end{array}$ & Comments \\
\hline Lecidea fuscoatra (L.) Ach. & & LC & $\mathrm{NE}$ & \\
\hline Lecidea lapicida var. pantherina Ach. & & LC & $\mathrm{LC}$ & \\
\hline Lecidella stigmatea (Ach.) Hertel \& Leuckert & & LC & $\mathrm{LC}$ & \\
\hline $\begin{array}{l}\text { Lichenomphalia umbellifera (L.) Redhead, Lutzoni, } \\
\text { Moncalvo \& Vilgalys }\end{array}$ & Omphalina umbellifera & LC & $\mathrm{LC}$ & \\
\hline Melanelixia fuliginosa (Fr. ex Duby.) O. Blanco et al. & Melanelia fuliginosa & LC & $\mathrm{LC}$ & \\
\hline Melanelixia subargentifera (Nyl.) O. Blanco et al. & Melanelia subargentifera & LC & $\mathrm{LC}$ & \\
\hline Melanelixia subaurifera (Nyl.) O. Blanco et al. & Melanelia subaurifera & LC & $\mathrm{LC}$ & \\
\hline Melanohalea exasperata (De Not.) O. Blanco et al. & Melanelia exasperata & LC & $\mathrm{LC}$ & \\
\hline Melanohalea exasperatula (Nyl.) O. Blanco et al. & Melanelia exasperatula & LC & $\mathrm{LC}$ & \\
\hline Melanohalea olivacea (L.) O. Blanco et al. & Melanelia olivacea & LC & LC & \\
\hline Parmelia saxatilis (L.) Ach. & & LC & $\mathrm{LC}$ & \\
\hline Parmelia sulcata Taylor & & LC & $\mathrm{LC}$ & \\
\hline Parmeliopsis ambigua (Wulfen) Nyl. & & LC & $\mathrm{LC}$ & \\
\hline Parmeliopsis hyperopta (Ach.) Arnold & & LC & LC & \\
\hline Peltigera aphthosa (L.) Willd. & & NT & $\mathrm{LC}$ & \\
\hline Peltigera canina (L.) Willd. & & $\mathrm{LC}$ & $\mathrm{LC}$ & \\
\hline Peltigera didactyla (With.) J.R. Laundon & & LC & $\mathrm{LC}$ & \\
\hline Peltigera leucophlebia (Nyl.) Gyeln. & & VU & $\mathrm{LC}$ & \\
\hline Peltigera malacea (Ach.) Funck & & LC & $\mathrm{LC}$ & \\
\hline Peltigera membranacea (Ach.) Nyl. & & VU & $\mathrm{LC}$ & \\
\hline Peltigera neckeri Hepp ex Müll. Arg. & & LC & LC & \\
\hline Peltigera neopolydactyla (Gyeln.) Gyeln. & & EN & $\mathrm{LC}$ & \\
\hline Peltigera polydactylon (Neck.) Hoffm. & & LC & LC & \\
\hline Peltigera praetextata (Flörke ex Sommerf.) Zopf & & LC & $\mathrm{LC}$ & \\
\hline Peltigera rufescens (Weiss) Humb. & & LC & LC & \\
\hline Phaeophyscia ciliata (Hoffm.) Moberg & & NT & $\mathrm{LC}$ & \\
\hline Phaeophyscia nigricans (Flörke) Moberg & & LC & $\mathrm{LC}$ & \\
\hline Phaeophyscia orbicularis (Neck.) Moberg & & LC & LC & \\
\hline Phaeophyscia sciastra (Ach.) Moberg & & LC & $\mathrm{LC}$ & \\
\hline Physcia adscendens (Fr.) H. Olivier & & LC & $\mathrm{LC}$ & \\
\hline Physcia aipolia (Ehrh. ex Humb.) Fürnr. & & LC & LC & \\
\hline Physcia caesia (Hoffm.) Fürnr. & & LC & $\mathrm{LC}$ & \\
\hline Physcia dubia (Hoffm.) Lettau & & LC & $\mathrm{LC}$ & \\
\hline Physcia stellaris (L.) Nyl. & & LC & LC & \\
\hline Physcia tenella (Scop.) DC. var. tenella & & LC & $\mathrm{LC}$ & \\
\hline Physconia distorta (With.) J.R. Laundon & & LC & LC & \\
\hline Physconia enteroxantha (Nyl.) Poelt & & LC & $\mathrm{LC}$ & \\
\hline Physconia perisidiosa (Erichsen) Moberg & & LC & LC & \\
\hline Placynthium nigrum (Huds.) Gray & & LC & $\mathrm{LC}$ & \\
\hline Platismatia glauca (L.) W.L. Culb. \& C.F. Culb. & & LC & LC & \\
\hline Pleurosticta acetabulum (Neck.) Elix \& Lumbsch & & LC & LC & \\
\hline Polycauliona candelaria (L.) Frödén, Arup \& Søchting & Xanthoria candelaria & LC & $\mathrm{LC}$ & \\
\hline Polycauliona polycarpa (Hoffm.) Frödén, Arup \& Søchting & Xanthoria polycarpa & LC & LC & \\
\hline Porpidia crustulata (Ach.) Hertel \& Knoph & & LC & $\mathrm{LC}$ & \\
\hline Protoblastenia rupestris (Scop.) J. Steiner & & LC & LC & \\
\hline Protoparmeliopsis muralis (Schreb.) M. Choisy & & LC & $\mathrm{LC}$ & \\
\hline Pseudevernia furfuracea (L.) Zopf & & LC & LC & \\
\hline
\end{tabular}




\begin{tabular}{|c|c|c|c|c|}
\hline $\begin{array}{l}\text { Species name (in bold if the species was assigned a threat } \\
\text { or the Near Threatened category) }\end{array}$ & $\begin{array}{l}\text { Species name used in } \\
2008\end{array}$ & $\begin{array}{l}\text { Red List } \\
\text { category in } \\
2021\end{array}$ & $\begin{array}{l}\text { Red List } \\
\text { category in } \\
2008\end{array}$ & Comments \\
\hline Ramalina baltica Lettau & & NT & $\mathrm{LC}$ & \\
\hline Ramalina farinacea (L.) Ach. & & LC & $\mathrm{LC}$ & \\
\hline Ramalina fastigiata (Pers.) Ach. & & LC & LC & \\
\hline Ramalina fraxinea (L.) Ach. & & LC & LC & \\
\hline Ramalina pollinaria (Westr.) Ach. & & LC & $\mathrm{LC}$ & \\
\hline Ramalina polymorpha (Lilj.) Ach. & & NT & $\mathrm{LC}$ & \\
\hline Ramalina subfarinacea (Nyl. ex Cromb.) Nyl. & & EN & $\mathrm{LC}$ & \\
\hline Rhizocarpon geographicum (L.) DC. & & VU & $\mathrm{NE}$ & \\
\hline Rimularia insularis (Nyl.) Rambold \& Hertel & & LC & $\mathrm{LC}$ & \\
\hline Sarcogyne regularis Körb. & & LC & $\mathrm{NE}$ & \\
\hline Scytinium lichenoides (L.) Otálora, P.M. Jørg. \& Wedin & Leptogium lichenoides & LC & $\mathrm{LC}$ & \\
\hline Stereocaulon paschale (L.) Hoffm. & & NT & $\mathrm{LC}$ & \\
\hline Stereocaulon saxatile H. Magn. & & EN & $\mathrm{LC}$ & \\
\hline Stereocaulon tomentosum $\mathrm{Fr}$. & & VU & $\mathrm{LC}$ & \\
\hline Tuckermannopsis chlorophylla (Willd.) Hale & & LC & $\mathrm{LC}$ & \\
\hline Umbilicaria deusta (L.) Baumg. & & NT & $\mathrm{LC}$ & \\
\hline Umbilicaria polyphylla (L.) Baumg. & & NT & $\mathrm{LC}$ & \\
\hline Umbilicaria torrefacta (Lightf.) Schrad. & & EN & $\mathrm{LC}$ & \\
\hline Usnea dasopoga (Ach.) Nyl. & Usnea filipendula & LC & $\mathrm{LC}$ & \\
\hline Usnea glabrescens (Vain.) Vain. & & VU & $\mathrm{LC}$ & \\
\hline Usnea hirta (L.) F.H. Wigg. & & LC & $\mathrm{LC}$ & \\
\hline Usnea lapponica Vain. & & $\mathrm{DD}$ & $\mathrm{LC}$ & \\
\hline Usnea subfloridana Stirt. & & LC & $\mathrm{LC}$ & \\
\hline Verrucaria muralis Ach. & & LC & $\mathrm{LC}$ & \\
\hline Vulpicida pinastri (Scop.) J.-E. Mattsson \& M.J. Lai & & LC & $\mathrm{LC}$ & \\
\hline Xanthocarpia lactea (A. Massal.) A. Massal. & Caloplaca lactea & LC & $\mathrm{LC}$ & \\
\hline Xanthoparmelia conspersa (Ach.) Hale & & LC & $\mathrm{LC}$ & \\
\hline Xanthoparmelia loxodes (Nyl.) O. Blanco et al. & Neofuscelia loxodes & $\mathrm{LC}$ & $\mathrm{LC}$ & \\
\hline Xanthoparmelia pulla (Ach.) O. Blanco et al. & Neofuscelia pulla & $\mathrm{LC}$ & $\mathrm{LC}$ & \\
\hline Xanthoparmelia stenophylla (Ach.) Ahti \& D. Hawksw. & $\begin{array}{l}\text { Xanthoparmelia } \\
\text { somloënsis }\end{array}$ & LC & $\mathrm{LC}$ & \\
\hline Xanthoria fulva (Hoffm.) Poelt \& Petutschnig & & LC & LC & \\
\hline Xanthoria parietina (L.) Th. Fr. & & LC & $\mathrm{LC}$ & \\
\hline Xylopsora caradocensis (Nyl.) Bendiksby \& Timdal & $\begin{array}{l}\text { Hypocenomyce carado- } \\
\text { censis }\end{array}$ & EN & LC & \\
\hline Xylopsora friesii (Ach.) Bendiksby \& Timdal & Hypocenomyce friesii & NT & $\mathrm{LC}$ & \\
\hline
\end{tabular}

